\title{
Yrittäjyyden edistämistä on tarkasteltava kriittisesti
}

\author{
Piritta Parkkari
}

Usein yrittäjyyden toivotaan tuovan talouskasvua ja työpaikkoja sekä ratkovan niin yhteiskunnan kuin ympäristön ongelmia. Lähes jokaista meistä yritetään saada harkitsemaan yrittäjyyttä uravaihtoehtona. Yrittäjyyskasvatuksella meistä yritetään kehittää oma-aloitteisia, aktiivisia ja innovatiivisia eli yrittäjämäisen ajattelutavan ja asenteen omaavia kansalaisia ja työntekijöitä (Laalo \& Heinonen 2016).

Halusin väitöstutkimuksessani ymmärtää, millaista toimintaa yrittäjyyden edistämiseen liittyy. Väitöskirjassani tutkin, mitä yrittäjyyttä edistävät organisaatiot tekevät. Tarkoitan yrittäjyyttä edistävillä organisaatioilla tahoja, jotka järjestävät toimintaa, tapahtumia ja tapaamisia saadakseen ihmiset kiinnostumaan yrittäjyydestä sekä innostaakseen ja tukeakseen ihmisiä kohti yrittäjyyttä. Minua kiinnosti, mitä yrittäjyyttä edistettäessä todella tullaan edistäneeksi. Miten yrittäjyys tulee ymmärretyksi ja mitä sen edistämisessä tavoitellaan? Millaisia yrittäjyyttä koskevia ihanteita muodostuu? Millaisia tulkintoja yrittäjyydestä tai millaisia identiteettejä toiminta mahdollistaa tai rajaa ulkopuolelleen?

Yhdistän tutkimuksessani kriittistä yrittäjyystutkimusta (ks. esim. Verduijn, Dey, Tedmanson \& Essers 2014) ja käytäntöteoreettista tutkimusotetta (ks. esim. Nicolini 2012), mitä ei ole juuri tehty empiirisessä yrittäjyystutkimuksessa. Kriittiset tutkijat ovat tuoneet esille, että yrittäjyystutkimuksessa ja käytännön toiminnassa yrittäjyyttä pidetään jopa itsestäänselvyytenä - asiana, jota tarvitaan aina lisää ja jota pitää edistää (Farny, Hedeboe Frederiksen, Hannibal \& Jones 2016). Tämän vuoksi yrittäjyydestä on haastavaa puhua kyseenalaisten. Kyseenalaistamista kuitenkin tarvitaan, koska ollaan vaarallisilla vesillä, jos jotain ilmiötä tai ideaa ei voi haastaa. Väitän tutkimuksessani, että yrittäjyyden edistämistä tulisi tarkastella kriittisesti, koska yrittäjyyden edistämisellä on vaikutuksia siihen, miten yrittäjyys ymmärretään ja millainen yrittäjyys nähdään haluttavana.

Käytäntöteoreettisen lähestymistapani myötä näen, että yrittäjyys saa vaihtelevia merkityksiä ja muotoja erilaisissa rutinoituneissa, suhteellisen vakiintuneissa sosiaalisesti jaetuissa puhumisen ja tekemisen tavoissa eli käytännöissä (Nicolini 2012). Esimerkiksi startup-tapahtuman pitchaus-kisa saa lavalla liikeideaansa esittelevän nuoren miehen näyttäytymään nykyajan rokkistarana ja ylipäänsä startup-yrittäjyyden näyttäytymään tavoiteltavana asiana. Työvoimatoimiston käytännöissä puolestaan liiketoiminta voi olla peruste evätä samaiselta mieheltä hänen hakemansa tuet. Näiden ristiriitaisten merkitysten takia on siis tärkeää tutkia erilaisia yrittäjyyteen liittyviä käytäntöjä sekä pyrkiä ymmärtämään, miten ja millaiseksi yrittäjyys niissä rakentuu. Tämän vuoksi omassa tutkimuksessani tarkastelen yrittäjyyttä edistävien organisaatioiden käytäntöjä.

\section{Opiskelijavetoisten yrittäjyysyhteisöjen käytännöt tutkimuksen kohteena}

Yrittäjyys on ollut viime vuosina runsaan mediahuomion kohteena. Huomiota on saanut erityisesti kasvukeskeinen startup-yrittäjyys. Tutkimukseni lähti liikkeelle siitä, kun törmäsin Entrepreneurship Society -nimisiin yrittäjyysyhteisöihin (lyhennettynä ES), jotka edis- 
tävät juuri startup-yrittäjyyttä ja järjestävät siihen liittyviä tapahtumia. Kiinnostuin näistä organisaatioista, koska ne ovat opiskelijoiden ja muiden nuorten aikuisten vetämiä. Ne eivät järjestä toimintaa yrittäjinä toimiville, vaan ovat pikemminkin yhteisö yrittäjyydestä kiinnostuneille sekä yrittäjyyttä koskevan kiinnostuksen herättämistä varten. Ne ovat myös kansainvälinen ilmiö, joka on vuoden 2009 tienoilta levinnyt laajalti ympäri Suomen korkeakoulukaupunkeja (Pittaway, Rodriguez-Falcon Aiyegbayo \& King 2011; Viljamaa 2016).

Halusin empiirisessä tutkimuksessani ymmärtää, mistä näissä yhteisöissä on kyse. Hyödynsin sen vuoksi etnografiaa menetelmänä. Tutkin pääasiallisesti yhtä keskikokoisessa suomalaisessa kaupungissa toimivaa ES-yhteisöä, jolle olen antanut peitenimen StartingUp. Keräsin aineistoa syyskuun 2013 ja joulukuun 2016 välillä siten, että osallistuin toimintaan ja havainnoin sitä kuvaamalla, videoimalla ja nauhoittamalla sekä haastattelin toimintaan osallistuneita ihmisiä.

Tarkastelemani toiminta piti sisällään StartingUpin tapahtumat, joissa yrittäjät kertoivat tarinaansa, opiskelijat pitchasivat liikeideoitansa tai joissa keskityttiin verkostoitumiseen sekä ilmaisen ruoan ja juoman nauttimiseen. StartingUp myös järjesti aloitteleville startup-tiimeille tarkoitetun kiihdytysohjelman. Lisäksi yhteisön viralliset ja epäviralliset tapaamiset ovat tärkeä osa aineistoa. Tutkimukseni tekemisen myötä minusta tuli aktiivinen jäsen StartingUpissa ja pääsin jäsenyyteni kautta tutustumaan Suomen ES-verkostoon sekä keräämään aineistoa verkoston tapaamisista.

Analyysissäni keskityin tulkitsemaan sitä, millaisia käytäntöjä yrittäjyyttä edistävässä organisaatioissa on ja millaista käsitystä yrittäjyydestä ja yrittäjistä näissä käytännöissä rakennetaan. Olen analysoinut erilaisista tilanteista sitä, keitä siellä on paikalla, mitä he tekevät ja sanovat, millaisessa tilassa toiminta tapahtuu sekä miten kehoja, teknologioita ja tavaroita tilanteissa käytetään (Gherardi 2012; Nicolini 2012).

\section{Yrittäjyys maailman muuttamisen välineenä}

Tutkimukseni empiirinen anti näyttää, mitä yrittäjyyttä edistävissä organisaatioissa tapahtuu. Tunnistin tutkimuksessani erilaisten käytäntöjen tuottamia ihanteita, jännitteitä ja ristiriitoja. Nämä tulivat näkyväksi siinä, ketkä pääsevät mukaan yrittäjyyttä edistävän toiminnan tuottamiseen, suunnitteluun ja kehittämiseen sekä siinä, mitä yrittäjyyden edistämisessä itse asiassa tavoitellaankaan.

StartingUp sai alkunsa aluekehittämisorganisaation projektina ja kehittyi siitä rekisteröidyksi yhdistykseksi. Samalla sen jäsenet verkostoituivat Suomen muiden ES-yhteisöjen kanssa. Yrittäjyyden edistäminen näyttäytyi ensin aluekehityksen tarpeista tulevana tavoitteena, jolloin yrittäjyyden edistäminen tapahtui projektien kautta ja projektipäällikkö oli vastuussa sen edistämisestä. Itse yrittäjyyden edistämisellä tarkoitettiin tällöin uusien yritysten perustamisen ja työpaikkojen luomisen tavoittelua. Näillä mitattiin projektin onnistumista.

Yrittäjyyden edistäminen näyttäytyi myös vapaaehtoisvoimin toimivan paikallisen yhteisön, tässä tapauksessa rekisteröidyn StartingUp-yhdistyksen, tavoitteena. Tämä yhteisö koostui 18-30-vuotiaista korkeakouluopiskelijoista ja jo työelämässä olevista nuorista aikuisista. Mukana oli niin suomalaisia kuin kansainvälisiä opiskelijoita. StartingUp-yhdistyksen toiminnassa yrittäjyyden edistäminen nähtiin enimmäkseen pyrkimyksenä tuoda erilaisia ihmisiä yhteen ja kehittää paikallisen alueen yrittäjyysilmapiiriä myönteisemmäksi. Esimerkiksi tiimikavereiden löytäminen nähtiin tärkeänä, mutta itse yritysten perustaminen enemmänkin sivuseikkana.

Yrittäjyyden edistäminen näyttäytyi myös laajemmin korkeakouluopiskelijoiden asiana. Havaitsin, miten Entrepreneurship Society -yrittäjyysyhteisöjen verkosto rakentui opiskelijavetoiseksi, startup-yrittäjyyttä edistäväksi yhteiskunnalliseksi liikkeeksi. Korkeakouluopiskelijat näyttäytyivät toimijoina, joil- 
la on halua ja kykyä vaikuttaa yrittäjyyden asemaan Suomessa. Tällöin yrittäjyyden edistäminen tarkoitti opiskelijoiden innostamista ja auttamista startup-yrittäjyyteen sekä yrittäjyyden kulttuurisen aseman ja sitä koskevien asenteiden muuttamista. Tulkitsen, että startup-yrittäjyys on ilmiö, jonka ympärille opiskelijat muodostavat liikkeen. Tämä on kiinnostavaa, sillä tyypillisesti yhteiskunnalliset liikkeet ovat pikemminkin haastaneet yrittäjyyteen usein liitettäviä ideologioita, kuten kapitalismia ja uusliberalismia sen sijaan, että ne kehottaisivat ihmisiä yrittäjyyden pariin.

ES-yhteisön jäsenet vertasivat "ES-liikettä" 1960- ja 70-lukujen poliittisiin opiskelijaliikkeisiin. Jäsenten mukaan ES-liikkeessä kuitenkin työskennellään kohti liikkeen tavoitetta, eli yrittäjyyden edistämistä, koska edistämistyö on hauskaa. Siinä pääsee tutustumaan uusiin ihmisiin, verkostoitumaan, kokeilemaan uusia asioita, kehittämään itseään sekä oppimaan opiskelijoiden käytännöllisinä ja tärkeinä pitämiä asioita, joita opiskelijat eivät koe oppivansa korkeakouluopetuksessa. Osallistuminen mahdollistaa myös tunteen siitä, että on mukana vaikuttamassa ja kuuluu yhteisöön.

Tulkitsin, että yrittäjyys nähtiin tutkimissani yhteisöissä haluttavana tapana muuttaa maailmaa. ES-yhteisöissä korostettiin tyypillisesti yrittäjyyteen liitettävän tekemisen merkitystä - siis ketterää, kokeilevaa ja yrittäjämäistä "tekemisen kulttuuria". "Pelkän puhumisen" ja "byrokratian" kaltaiset asiat nähtiin vastakohtaisina sille, mikä yrittäjyysyhteisöissä on tärkeää. Yhteisöissä jopa pyrittiin pysymään mahdollisimman kaukana "politiikasta" ja nähtiin, että yrittäjämäisellä "tekemisellä" saadaan aikaan suurempi muutos.

Vaikka tekemisen meininkiä arvostettiin, eivät tutkimieni yhteisöjen käytännöt aina mahdollistaneet esimerkiksi tapahtumissa yleisön aktiivisuutta. Puhujatapahtumien kaltaiset käytännöt, joissa yrittäjät kertoivat vaikeuksista voittoon kulkevaa tarinaansa, asettavat yleisön pikemminkin passiiviseen, inspiraation ja opin vastaanottajan rooliin. Tällaiset käytännöt myös ylläpitävät stereotyyppistä kuvaa yrittäjistä sankarimaisina yksilöinä. Yrittäjyyteen liitettävä usko siihen, että "kaikki on yksilön omissa käsissä", voi pitää mukanaan riskin yksilön yrittäjämäisen toimijuuden ylikorostumisesta. Tällöin yksilö näyttää olevan vastuussa niin omista onnistumisista kuin epäonnistumisistakin, vaikka näihin tosiasiassa vaikuttavat lukuiset tekijät.

Startup-yrittäjyys rakentui ES-yhteisöjen käytännöissä juuri siksi yrittäjyyden muodoksi, jota yhteisöt edistävät. Tässä ihanteessa korostuivat tiimipohjaisuus, skaalautuvuus, kasvu, teknologia ja ratkaisujen hakeminen. Erityisesti tiimien merkityksen korostaminen rikkoi yrittäjyystutkimuksen tunnistamaa stereotyyppistä kuvaa yrittäjistä sankariyksilöinä.

Startup-ihanne vaikuttaa eri toimijoiden toimintamahdollisuuksiin. Se sai perinteisenä pidetyn yrittäjyyden näyttämään sellaiselta, jonka tekemiseen ei tarvita yrittäjyyttä edistävien tahojen apua. Toimijat, jotka pyrkivät esimerkiksi täyttämään paikallisia tarpeita eivätkä tavoittele suurta kasvua ja haluavat hyödyntää jo tunnettuja liiketoimintamalleja, eivät näyttäytyneet halutun kaltaisina yrittäjinä.

\section{Huomio yrittäjyyden edistämisen käytäntöihin}

Johtopäätöksenä totean, että yrittäjyyden edistäminen ei ole neutraalia toimintaa, vaan se pitää sisällään erilaisia ihanteita, jännitteitä ja ristiriitoja. Yrittäjyyttä edistävien organisaatioiden käytännöt voivat yhtäaikaisesti ylläpitää ja haastaa vallitsevia ymmärryksiä yrittäjyydestä. Niissä myös uusiutuu taipumus liittää yrittäjyys myönteisiin asioihin. Yrittäjyys näyttäytyy haluttavana ja tavoiteltavana asiana eikä sen tavoiteltavuuden kyseenalaistamiselle juuri ole tilaa. Voidaankin nähdä, että yrittäjyyttä edistävien organisaatioiden toiminta kertoo siitä, miten yrittäjyysajattelu on levinnyt Suomessa ja miten nämä organisaatiot omalla toiminnallaan levittävät sitä edelleen.

Tutkimukseni teoreettinen anti yrittäjyystutkimukselle on kriittisen ja käytäntöteoreet- 
tisen yrittäjyystutkimuksen keskustelujen yhdistäminen. Käytäntöteoreettinen lähestymistapa mahdollistaa sen tutkimisen, miten yrittäjyys rakentuu käytännöissä. Se kasvattaa kriittisen yrittäjyystutkimuksen teoreettista kirjoa ja muistuttaa, että yrittäjyyteen liittyviä ongelmallisia ulottuvuuksia pidetään yllä jokapäiväisessä toiminnassa. Se kehottaa kohdistamaan kritiikin käytäntöihin, sillä avain asioiden muuttamiseen on käytäntöjen muuttamisessa.

Kriittinen ote puolestaan täydentää käytäntöteoreettista keskustelua kehottamalla pohtimaan, mitä ja kenen käytäntöjä tulisi tutkia. Oma tutkimukseni haastoi yrittäjyyden käytäntöteoreettista tutkimusta siirtämällä huomion yrittäjiksi nimettyjen ihmisten käytännöistä laajemmin kohti yrittäjyyteen liittyvää toimintaa. Kriittinen ote myös kehottaa käytäntökeskustelua olemaan ottamatta yrittäjyyden "hyvyyttä" annettuna ja tarkastelemaan kyseenalaistavasti, mitä yrittäjyyteen liittyvissä käytännöissä rakentuu.

Väitän, että yrittäjyyden edistämistä on tarkasteltava kriittisesti, jotta ymmärrämme, mitä yrittäjyyden edistämiseen liittyvässä toiminnassa rakentuu. Sanomani yrittäjyyden edistämisen parissa toimiville käytännön toimijoille on, että kiinnittäkää huomiota käytäntöihinne eli vakiintuneisiin tekemisen ja puhu-

\section{Kirjallisuus}

Farny, S., Hedeboe Frederiksen, S., Hannibal, M. \& Jones, S. (2016) A CULTure of entrepreneurship education. Entrepreneurship \& Regional Development 28 (7-8), 514-535. https://doi.org/10.1 080/08985626.2016.1221228

Gherardi, S. (2012) How to Conduct a PracticeBased Study. Problems and Methods. Cheltenham and Northampton: Edward Elgar. https://doi.org/10.4337/9780857933386.

Laalo, H. \& Heinonen, J. (2016) Governing the entrepreneurial mindset: Business students' constructions of entrepreneurial subjectivity. European Educational Research Journal 15 (6), 696-713. https://doi.org/10.1177/1474904116662288

Nicolini, D. (2012) Practice Theory, Work, and Organization. Oxford: Oxford University Press. misen tapoihin. On tärkeää katsoa oman toiminnan tahattomiakin seurauksia. Millaista kuvaa yrittäjyydestä tullaan edistäneeksi ja millaista maailmaa omalla tekemisellä luodaan? Muodostuuko toiminnassa esimerkiksi sellaisia ihanteita, jotka jättävät tietynlaisia ideoita tai ihmisiä ulkopuolelle?

Korkeakouluille haluaisin sanoa, että huomioikaa opiskelijoiden yrittäjyyden eteen tekemä työ ja heidän tulkintansa siitä, mikä yrittäjyyden edistämisessä on tärkeää. Korkeakoulujen on hyvä myös kiinnittää huomiota siihen, millaisia tulkintoja yrittäjyydestä erilaiset yrittäjyyden edistämisen käytännöt tuottavat.

Piritta Parkkarin yhteiskuntatieteiden väitöskirja Doing Entrepreneurship Promotion: A Critical, Practice Theoretical Study of Entrepreneurship tarkastettiin Lapin yliopistossa 29.5.2019. Teos löytyy sähköisessä muodossa osoitteesta http://urn.fi/URN:ISBN:978-952-337-153-8

\section{Kirjoittaja}

Piritta Parkkari, YTT, TKI-asiantuntija, Kaakkois-Suomen ammattikorkeakoulu, sähköposti: piritta.parkkari@xamk.fi

Pittaway, L., Rodriguez-Falcon, E. Aiyegbayo 0. \& King, A. (2011) The role of entrepreneurship clubs and societies in entrepreneurial learning. International Small Business Journal 29 (1), 37-57. https://doi.org/10.1177/0266242610369876

Verduijn, K., Dey, P., Tedmanson, D. \& Essers, C. (2014) Emancipation and/or oppression? Conceptualizing dimensions of criticality in entrepreneurship studies. International Journal of Entrepreneurial Behaviour \& Research 20 (2), 98-107. https://doi.org/10.1108/IJEBR-02-2014-0031

Viljamaa. L. (2016) Yrittäjyyden tukemisen hyvät käytänteet korkeakouluissa. Opetus- ja kulttuuriministeriön julkaisuja 14. Helsinki: Opetus- ja kulttuuriministeriö. 